\title{
PSYCHOANALYTIC DISCOURSE OF THE 1920s-1930s UKRAINIAN NOVELLAS
}

\author{
NATALIA MAFTYN
}

\begin{abstract}
The article highlights the impact of Freud's ideas on the Ukrainian prose between the Two World Wars. The analysis of the works by V. Pidmohylnyi and I. Cherniava shows that in literary texts, the erotic-death paradigm is one of the 'modernist' algorithms for plot development; in the novellas, this paradigm affects the process of conflict modeling and conflict development. It is rightly believed that V. Pidmohylnyi's dominant literary interest was the 'helplessness of human morality before the temptations of crime'. In the novella analyzed in this study, Pidmohylnyi adopts the perspective of the ontogenesis of the human soul at the age of puberty. I. Cherniava explores the theme of subconscious 'temptation of crime' a wicked and thoughtless children's game is sure to unleash. The two stories have many features in common: they are thematically close; in both of them, the plot is based on the Freudian ideas; stylistically, they are realist-oriented works with certain elements of naturalism. The novellas belong to the same type of structurally modified literary works, in which the action is no more important than the resultant psychic changes in the characters.

In both novellas, the plot is built around stable structural-behavioural patterns of human culture (in Vania, it is the initiation trial pattern; in The Execution, the perverse play pattern, the game of a trial transformed into a crime). Both works have rather specific expositions, which fulfill the function of 'Vorgeschichte' - they tell a reader about certain psychic inclinations of the characters and present the projection of the central theme. In both novellas, the plot type, which determines the development of action, is outlined in the prehistory. Structurally, the two novellas are based on parallelism of events. As to their style, both works bear the features of naturalism.
\end{abstract}

Keywords: erotic-death paradigm, Freudism, plot, novella, Vorgeschichte (prehistory), Spannung (tension), ontogenesis, initiation, pointe (crisis), coda, naturalism.

The Ukrainian prose of the late $19^{\text {th }}$-the early $20^{\text {th }}$ century, as well as the Western European prose of the period, was significantly affected by the ideas of F. Nietzsche and S. Freud. Interest in the postulates of Freudism can be traced in Ukrainian literature throughout the period from V. Vynnychenko (in whose prose the features of this theory are quite evident) to the Renaissance of the 1930', later transformed into a horrible hecatomb of the 'Shot Renaissance'; then there was the socialist realism dead end. The erotic-death paradigm of social ontology developed in Freud's major works becomes one of the general algorithms for plot construction in the literature between the Two World Wars; this paradigm determines the nature of conflict and its development in prose pieces. As cultural universals, Eros and Thanatos have always been the focal point for endeavours in every area of art, since 'the 
virtual world of artistic reality is strictly speaking the projection of the deep existential opposition between life and death, the main opposition in human culture, onto this reality' [2, p. 6-7].

It was the popularity of the Freudian psychoanalysis that made some artists highlight the issue of conflict between human instincts and civilizational taboos, show how human behavior is determined by something unruly and cruel - so-called 'dragons of Eden' that live deep inside us, in subconsciousness of civilized human beings. Of special interest for the creators of intellectual prose was the connection between the sexual and death instincts studied by Freud; according to him, the desire to experience pleasure is related to the death instinct. Later, the problem was addressed by E. Fromm (The Human Situation, The Anatomy of Human Destructiveness), E. Canetti (Crowds and Power), G. Bataille (The Tears of Eros), V. Rosov (The Nature of Sexuality), J. G. Bertram (Flagellation and the Flagellants: A History of the Rod).

Working on the theory of neurosis, Freud made a conclusion that 'neurotic symptoms are substitutes for sexual satisfaction' and that '...all inclinations to perversion have their origin in childhood, that children have tendencies toward them all and practice them in a measure corresponding to their immaturity' [11]; [7, p. 310]. The Austrian neurologist looked into the factors leading to neuroses; he analyzed the main phases of libidinal development and made quite a few conclusions valid for scientific, culturological, and artistic discourses of his time - conclusions concerning the influence of early childhood libido manifestations on the development of the human psyche, a factor behind 'asocial' human behavior.

'The helplessness of human morality before the temptations of crime', especially at the early stage of human development, in childhood or adolescence, when civilizational taboos are not yet a strong vise to curb uncontrolled desires of the 'dragons of subconsciousness' is the dominant theme in V. Pidmohylnyi's prose. In Vania, one of his early works, the author depicts the reaction of a child (deep neurosis) to the manifestation of the dark side of his subconscious nature - 'alienation that takes the form of an individual's confrontation with himself' (M. Tarnavskyi).

V. Pidmohylnyi wrote his novella in 1919; sixteen year later, the Western Ukrainian magazine My (We) published a novella by Ivan Cherniava, a member of the Lviv bohemian literary society Dvanadtsiat (The Twelve); the title of the novella is Eksekutsia (The Execution). The author also explores the theme of subconscious 'temptation to commit crime', which has developed from a seemingly innocent children's game. There is no evidence about Cherniava's acquaintance with the novella by Pidmohylnyi, but the theory of the famous Austrian neurologist remained quite popular in Western Ukraine in the late 1930s, when the Soviet Ukraine had already been plunged into horrors of the Bolshevik regime. The two stories have many features in common: they are thematically close; in both cases, the plot is based on the Freudian ideas; stylistically, they are realist-oriented works with certain elements of naturalism. (All the quotations from Pidmohylnyi's and Cherniava's original texts are translated from Ukrainian $[4 ; 8])$.

Thus it may be suggested that they belong to the same type structurally modified literary works, in which the action is no more important than the resultant psychic changes in the characters.

The plot of Pidmohylnyi's story is built around an event which cannot be called 'extraordinary': the two boys feeling sorry for a fatally injured dog finish it off; this is regarded as a motivation factor in psychic changes one of them sustains. At the structural level, the first part of the novella is a conventional 'Vorgeschichte'; though it is here, in the description of madness that covered the children with its dark wings, that the story reaches its culmination; a chain reaction triggers the second part of the work, where the action plays a much less important role.

In the first part, a reader meets Vania, an only child of the rich, loving parents, who take care of him and educate him (including labour education). Vania has his secret dreams and fears. The author tells us that 'Vania was afraid of the steppe'. His wish to grow a crop on a secret farming patch in the steppe helps the boy to overcome his inner fear. The scariest thing about the steppe is a gully: '... for a long time, trembling with fear, the boy was looking at it; it was terribly silent and mysteriously enigmatic. It seemed to Vania that the very earth had parted waiting for someone to get into its depth. Then slowly, with stubborn 
determination, the walls of the gully would start closing in and, indifferent about mad cries and wild thrashing, they would crash their careless victim and would draw apart again to lure people into its trap' [4, p. 58].

We do not know whether the author was well-acquainted with the theory of psychoanalysis at the time when he was working on his novella. Pidmohylnyi's critical 'attempt at psychoanalysis of the works' by I. Nechui-Levytskyi was published in 1927, when Freud's ideas had already received general acclaim. Though we may presume that having a perfect knowledge of French and reading foreign periodicals, the author might have been acquainted with Freud's theory. In my opinion, there is a distinct echo of the Freudian 'Oedipus complex' in Vania. In the novella, the archetypal meaning of the abyss, a deep depression in the ground, a gully is not only associated with threat; it develops a chthonic meaning of the grave (the earth as a grave) treacherously waylaying its victim. The boy, who has a deep affection for his mother, is subconsciously alarmed by the danger coming from the engulfing depths of Mother Earth. (The parallel between a boy's erotic attraction for his mother, which transforms into Oedipus complex and may take the form of necrophilia in adulthood, and the death motif of the earth as a grave is drawn in The Human Situation by E. Fromm).

Vania's inclination for neurosis is clearly revealed in the scene of his fight with an imaginary cannibal. I believe in the structure of the novella, this episode is of special importance. It is not only the author's favourite device of drawing parallels between the events in the story and transformations of the character's psyche. According to M. Tarnavskyi, here the author emphasizes Vania's vivid imagination and courage; but he also gives a projection of a terrible symptom the child will develop later. 'Having understood that it was a cannibal who had caught hold of his shirt, who would not let him go, but would eat him, Vania gave an agonized cry; then he tore off. Screaming his head off, he could not breathe. He kept shrieking violently, the echo of his shrieks bounced off the walls of the gully; he looked neither left nor right and only heard heavy steps behind him; he fell to the friable ground knocking his head against it, scratching it with his hands in deathly horror' [4, p. 59].

Later Vania decided never to come near the scary gully; yet the place had some 'strong magnetism'; the boy 'was attracted by the mysteries hidden securely between its friable yellow walls'. It turns out, though, that the real life has no less horrors than the imaginary one. The boy sees them in the eyes of Zhuchok (Little Bug), a mad dog. 'In the dog's dull look, in his eyes, red and empty, in his open drooling mouth, Vania saw the thing that is called madness. Vania did not know, nor did he understand what it was; but his heart told him that its power was persistent and destructive, and he got frightened' [4, p. 61].

The structure of the novella, its triple 'trial pattern', is the trigger mechanism for the 'transition ritual' - initiation: Vania starts his journey from childhood to adulthood and he has to fight all sorts of evil forces. In the scene with a 'cannibal', they come from the outer world, while Vania's next trial, the one in the forest, lifts the veil on one of the greatest mysteries of the world of adults: evil lives not somewhere there, it hides itself in a person's inner world waiting for the moment to reveal itself.

This idea is reinforced with the image of a forest - the archetypal symbol of subconsciousness and dangers. 'The forest was big and dense. Entering it, you got into a different world. On the one side of the wall of trees there were life, sunshine, day; on the other, death and cold night. It smelled of damp soil and plants; grey and yellow last year's dead leaves and dry, fallen branches rustled and creaked under your feet; the trees silently raised their gray trunks covered in mould and moss. High above, the tops entwined in a kiss; in their dark density, which blocked the brightest daylight, vibrated the songs of the forest itself-as sad as grief' [4, p. 62].

The description of the forest is not only a psychological background for the development of the plot; it is a metaphor that reveals the inner state of the character - the unleashing of the 'dragons of Eden' (C. Sagan), which can result in a person's self-alienation.

Pidmohylnyi's little characters still have non-desecrated 'virginity of soul'; they are not ready to resist dark and strange forces, whose wild shadows scare them in the outer world. In the scene of beating a mad dog to death, these forces reveal themselves as an incomprehensible and horrible part of the boys' subconsciousness. '... they hurled big stones, their breathing heavy, remembering nothing and having no other desire than to hit Zhuchok and to finish him off. Their faces grew long and pale, and sometimes glowed with madness; their eyes were wide, bright, vacant, and wild. When there were no more stones to hurl, they took heavy sticks, and those sticks hit Zhuchok with short, stifled, slapping sounds. They hit him till the 
sticks fell out of their trembling hands. They experienced a sharp feeling of dissatisfaction - they would keep on hitting but were too tired, and a new thrilling indignation came over them. Vania was already wheezing and panting, and was ready to drop; Mytka was only puffing and swallowing saliva. They exchanged glances and by some unspoken agreement moved closer to Zhuchok to grab him, to tear him to pieces, to tear out his eyes and tongue, to bite his body; but having looked at him, they stopped' [4, p. 63].

The first part of the novella ends with the description of stress Vania experiences after such a startling revelation about this inner demon of his; it is the loss of his 'virginity of soul'. 'He felt that something ugly had been done. It tormented him gnawing at his heart. Then he felt sorry for something, as if something had already been broken, crushed, and could not be repaired'.

Pidmohylnyi's work is a psychological novella. The plot is an important factor in its structure; still it is built around the changes in the posttraumatic psyche of the character. The author alternates 'static and dynamic aspects' (A. Reformatskyi), now increasing tension to the culminating point, now lessening it in order to encapsulate the essence of the story in the unexpected ending.

The initial sentence of the novella's second part - 'After the incident with Zhuchok, Vania became thoughtful and reserved' - creates a static effect and releases tension. At the beginning of the second part, the author starts 'stringing' details, which is typical of the smooth narrative style of novellas and some other genres of small prose (for example, short stories). This strategy - detailed description of the changes in the psyche of the main character - is another evidence of the idea suggested above. Vania becomes interested in horror tales, stories about hell; he has lost interest in playing with the other kids; he seems to forget about his vegetable patch. His imagination is full of the pictures of probable punishments for what he has done; then fears start coming at night - 'into the space between the bed and the wall, some creature was thrusting its paws and scratching the wall'. Hallucinatory images evoked by the sense of guilt and gathering neurosis ('either his mother or granny was sitting by his bedside, yet he knew that the black paws would appear from under the bed and he would hear the snapping of teeth') make the boy go to the place associated with his greatest fear and beg what-wasleft-of-Zhuchok's forgiveness. But the awful realization of his guilt - 'it is his fault that this revolting, horrible stuff is all that is left of Zhuchok' - triggers a new bout of aggression. 'Anger, sudden and overpowering, flared up and Vania, his eyes burning, started trampling on the rotting flesh that was squelching under his feet'. It may seem that this act will help Vania to get rid of his fear (as it was in the case with a 'cannibal').

'I am not afraid of you, damn you, you don't want to forgive, take that!' cried out Vania and having finished the wild outrage, the started laughing; his laughter echoed over the indifferent swamp and died in the reeds.

'I am not afraid of you', said Vania determinedly and went home [4, p. 69].

At home he tells his mother she does not have to sit by his bedside - nobody will scratch the wall any more. But at night, the 'dragons of subconsciousness' start their bloody hunt; in his dream, Vania sees a big viper coiling around his neck, then Zhuchok sinks his teeth deep in the boy's throat. The hallucinations chased off into the deepest corners of his subconsciousness in the daytime attack Vania like a terrible wolf pack at night. It is Vania's nightmare that the author presents as the highest point of tension ('Spannung'), the extreme culmination. 'Vania jumped up and ran ... At the door something dark, slippery, and cold fell on him. It seized his entire body pressing on all sides, it got into his mouth causing a nasty nausea; he was writhing, bending, pushing it back with his arms and legs, wheezing, muttering something unintelligible' [4, p. 70].

A true master of novella, the Maupassant-type writer, Pidmohylnyi releases tension at once: the boy is contorted in near-death agony and the author lets him wake up. 'He felt life freezing in his body, he jerked forwards with supernatural force, flung off the slithery creature, his breathing ragged, and woke up'. But so-called 'pointe', 'sharp point', crisis is an obligatory element of the novella structure. The author's final chord is unexpected; the story ends with a 'dynamic moment, as the dominant in music'. 'At that very moment, there started angry scratching noises and persistent snapping of teeth under his bed. Vania gave a wild shriek and fainted' [4, p. 70].

M. Tarnavskyi asks a question, 'What really happened to Vania in the forest?' His intuition of a scholar helped him to find the right answer. '... the boy's coming to the remains of Zhuchok is a 
symbolic representation of the discovery of sexuality. In the forest, the boy discovers the truth: there is something in him that scares him, something beyond his comprehension. Is it sexuality or something else? Whatever it is, it is a problem of human existence. From the literary theme perspective, it is alienation that takes the form of an individual's confrontation with himself' [6, p. 59].

Pidmohylnyi uses the Freudian method to create his novella, a typical genre piece, which is actually an artistic analysis of traumatic changes in a child's psyche determined by 'an individual's confrontation with himself'. The general algorithm of the plot construction is the ontological eroticdeath paradigm examined through the magnifying glass of Freudism. The author manages to combine the diagram of his character's emotional upheavals, which result in a deep neurosis, with the pulsating tension of the novella, which perfectly fits into the genre's framework.

At the beginning of the $20^{\text {th }}$ century, Freud's analysis of subconscious phenomena and processes penetrated all the fields of the humanities; Freudism became, in a sense, a world view factor; and for the Bohemia, a fashion, a thing that incites a person to lift the veil on the mysteries of the development of human ego and to show various perversions of human psyche. Evidently, the idea to combine exquisite composition with psychoanalytic research on the nature of human aggression seemed interesting to Ivan Cherniava, a Lviv author, a member of the bohemian literary society Dvanadtsiat (The Twelve). The original title of his novella Eksekutsia (The Execution) is Yanholiata (Little Angels). (Another Lviv author B. Nyzhankivskyi recollects that Cherniava was reading the novella to his friends in the Café de la Paix.) The work was published in the Warsaw-based magazine $M y(W e)$ in 1935 and republished only in 2006 in the unban prose anthology edited by Vasyl Gabor*.

Almost sixteen years passed since the publication of Pidmohylnyi's novella. This fact is a clear evidence of the continuity of the tradition established in the early $20^{\text {th }}$ century Ukrainian literature - the desire to contribute to the common European cultural discourse, to combine the genre cannons with the ideas explored and discussed in Europe. The problems of subconsciousness, the sexual and death instincts, human destruction and the factors behind it always remain the focal point of much discussion. Though it was the $20^{\text {th }}$ century, the 'wolfhound age' (O.Mandelshtam), with its bloody dawn flaming over Europe since the late $19^{\text {th }}$ century that focused on the issue. In Ukrainian prose they were addressed by I. Franko, M. Kotsiubynsky, V. Vynnychenko, V. Pidmohylnyi. Yet it should be admitted that Freud's ideas were not very popular in Ukrainian literature. 'None of the articles published in LNV (Literaturno-naukovyi visnyk - Literary-Scientific Magazine) in the first decade of the $20^{\text {th }}$ century made any reference to Freud. Nor was he mentioned by the writers. The intellectual revolution which took place 'next door', in Vienna, passed unnoticed by the early $20^{\text {th }}$ century Lviv' [5, p. 249]. One of the pioneers who applied Freud's ideas to literary analysis was S. Baleř; his research $Z$ psykholohii tvorchosti Shevchenka (From the Psychology of Shevchenko's Works) was published in 1916. At the time when Cherniava was writing his novella, psychoanalysis was no longer perceived as exotica, though it was not especially popular in literature - the socially and nationally concerned authors promoted some other ideas. That is why Cherniava's using the principles of psychoanalysis in literature may be regarded as searching one's own artistic path.

Psychoanalysis has proved the connection between pain and sexual sensations, aggression and the sexual instinct as realizations of the sado-masochist complex in both the victim and the executioner (S. Freud. Beyond the Pleasure Principle, 1920). In order to build the plot, Cherniava uses the psychological study of the deepest corners of the human soul, its ontogenesis. Another pillar of the novella's structure is the ritual sacrifice pattern presented here as a play with death, which gets out of control.

The novella's plot develops as a game of 'execution' played by a small group of children; having overheard the adults' conversation, the children conclude that hanging must be the most pleasant death for a criminal. They try to mimic such an attractive behaviour pattern distributing the roles of the criminal, the judge, the hangman and his assistants, the wife of the convicted, and the priest. Even the motivation factor for passing a sentence and the execution is the same as in the world of adults -

\footnotetext{
* "Dvanadtsiatka”. Naimolodsha lvivska literaturna bohema 30-kh rokiv XX stolittia: Antolohiia urbanistychnoi prozy / nauk. red. ta prym. Vasylia Habora. Lviv: LA "Piramida”, 2006. - 344 s.
} 
breaking the law. Though all the children want to get the honourable role of the criminal, the choice is predetermined by a real-life event: yesterday, Romtsio's father told him off and the boy bit his father's hand.

In the structure of Cherniava's work, as well as in the novella by Pidmohylnyi, the 'Vorgeschichte' is an important element; though in this case, the prehistory lacks one of its typological features imperfectness. In my opinion, the prehistory should be regarded as exposition, 'exemplification of direct description'. It is here that the author presents the characters, their specific 'markings', and indicate the story type, which predetermines the development of the plot. It can be argued that both Cherniava and Pidmohylnyi employ the strategy of parallelization of the main elements of the action.

It is a wonderful spring day. But for a small bunch of boys there is only one thing in the world their new 'game':'... a grasshopper is writhing in the children's hands. Petrus is firmly holding the insect by the wings. In the other hand the boy has an old rusty needle for sewing sacks.

The children are apprehensively watching the movements of the needle. A look of some intense pleasure is spread over their faces. The procedure is nearly over. Petrus has finished putting out the grasshopper's eyes and now tremulously and cautiously is piercing its belly. The boy is trembling all over. His lips are nervously apart, his even teeth are gleaming like the teeth of some small predator. His fingers have crumpled up and torn the grasshopper's wings. He is pressing them ever more tightly with some unexpressed feeling of exaltation and pleasure that borders on pain' [8, p. 279].

A short description of nature - 'The sun shines above it all. The spring sun shines and the silence of a hot day is undisturbed' - emphasizes the author's bitter irony and implicates the depravity of the human being, who is marked with the brand of the Fall from their birth (which is clearly evident from the original title of the novella). The summer day is so nice. But the children feel bored. 'The intense minutes of attention and pleasure of torturing the grasshopper have passed, now everything seems unattractive and grey to them' $[8, \mathrm{p} .280]$.

Their boredom disappears with the coming of Lialia and Bohdanchyk, the children of the town's only lawyer. Lialia is excited - they have devised a new game. Yesterday, the children overheard their father telling mother about the execution of a convict, and they decided to play a game of 'execution'. The girl brings animation into the boys' company - Surrounded by a small group of boys, she is standing like the queen among her subjects; light like a butterfly and tempting like a real woman. Here the accent is on the 'erotic' aspect of the image, and the author supports it with the girl's pronounced inclination for destruction (she tells she has tortured a cat to death). The children eagerly start the preparation for the game; every role should be convincing. In the process of the game, everyone feels some strange anxiety and nervousness as if it all were real. The children get carried away and unwittingly cross the line of a potentially dangerous play with death. From the dark corners of subconsciousness creeps out curiosity akin to the pleasure of torturing the grasshopper: '... now their eyes are feverishly bright with morbid curiosity as it was when a half-dead grasshopper was twitching in Petrus's hands' [8, p. 283].

Little Romtsio, a snare around his neck, feels some vague child's fear, but he is also hypnotized with a never experienced emotion, and he does not resist.

The tension reaches its peak - Vova the 'hangman' kicks the chair out from under Romtsio's feet. 'The hanged child is wheezing and chocking, uttering a cascade of wild, horrible cries. The child's short legs are oddly kicking air' [8, p. 284].

The genre canons require that emotional culmination should alternate with a turning point surprise. There is a covert 'Wendepunkt' (turning point) in the novella, which works only at a reader's level of perception: to the very last moment a reader hopes that Romtsio will be saved. It would be a predictable end though; the author's conception is somewhat different. Being hypnotized with the game, Lialia tells the 'hangman' to pull the hanged down by the legs. 'There was a crack in the air. A soft, fleshy body of the child is stretching and getting stiff. A swollen tongue that has turned blue is lolling out of the gaping mouth contorted in an inhuman grimace. Lialia wants to say something, she even puts out her hand towards the hanged boy. But for some reason, the words get stuck in her throat' [8, p. 284].

The tension curve leaps up dramatically; now a reader is stressed not so much by what has happened as by the reaction of the participants of the game - the children freeze in a state of near shock 
as the horrible truth reveals itself. Evil as a fantastic djinn, which they unleashed playing their wicked and thoughtless game, is rising before them in all its uncontrollable might. A terrible grimace of death suddenly shows them their own irreversible involvement in evil-doing, the tragedy of being marked with the stamp of Cain's crime. 'Suddenly the evening wind rises. And a small swollen corpse starts swinging gently. Abruptly and hastily, Lilia covers her face with her hands. Conscious of what has happened, she is filled with cold, unbearable horror. Sharp, wild cry escapes her dry throat' [8, p. 285].

Lialia darts forward. She is running into the gloomy, silent depths of the forest; now in the face of the horrible truth emerging before the child, the forest does not scare her any more.' The traditional novella ending, in which form is supposed to be a more important factor than content, is somewhat modified in Cherniava's work. Still, from the point of view of the plot's rhythmic pattern, the 'pointe' is preserved - the novella ends with a 'dynamic moment'. Cherniava's story, as well as Pidmohylnyi's work, is open-ended.

Further possible events, finding out whether the crime will be punished and how it will affect the little criminals are not important. The author wants to highlight the ontological problem of a play with death, unwitting realization of the primitive destructive instinct inherent in human subconsciousness, the instinct related to aggressive attractiveness (A. Adler). The novella's original title (Little Angels) correlates with Freud's conclusion that the 'death instinct' is inherent in children's psyche. 'The child is supposed to be pure and innocent, and whoever says otherwise may be condemned as a shameless blasphemer of the tender and sacred feelings of humanity.

The children are the only ones who do not join in carrying out these conventions, who assert their animal rights, who prove again and again that the road to purity is still before them' [11]; [7, p. 312].

The structural 'matrix' of The Execution is the play pattern. Being older than culture, play is a factor in the development of the latter. J. Huizinga, the Dutch cultural historian, discusses the role of play in human civilization, "Play is based on the manipulation with certain images - on a certain "imagination" of reality' [9, p. 14]; [1, p. 10].

At some point in Cherniava's novella, this order is completely reversed: the images that for the children are the representations of the adult world (the executioner and the victim - the main opposites in the aggressive human society) transform into a horrible reality. In a perverse children's game, conventional cruelty of human society breaks out of the civilizational vise and makes the participants a real executioner and his victim. Children are not yet experienced enough to oppose their own destructive instincts and they are not aware of the danger hiding in their subconsciousness. 'Living is a perpetual heavy effort not to lose sight of ourselves, to stay solidly present in ourselves, in our stasis. Step outside ourselves for a mere instant, and we verge on death's dominion', says Milan Kundera about the greatest existential threat to humanity of the human being in his Testaments Betrayed: An Essay in Nine Parts [10]; [3, p. 7].

In conclusion, the works by V. Pidmohylnyi and I. Cherniava share a number of typological features. The first one is compositional peculiarities determined by the chosen general algorithm for the development of the plot (the Freudian erotic-death ontological paradigm and ontogenesis of the human soul at the age of puberty). In both cases, the plot is built around stable structural-behavioural patterns of human culture (in Vania, it is the pattern of the initiation trial; in The Execution, the perverse play pattern, the game of a trial transformed into a crime).

Both works have rather specific expositions, which fulfill the function of 'Vorgeschichte' - they tell a reader about certain psychic inclinations of the characters and present the projection of the central theme. In both novellas, the type of the plot, which determines the development of action, is outlined in the prehistory (in Vania, it is the scene with a 'cannibal' and fear as a motivational factor for aggression; in The Execution, the torturing of an insect that reveals the children's inclination towards sadism: the children from the lowest social class and those of the town's only lawyer are not new to 'aggressive magnetism'). Structurally, both novellas are based on parallelism of events; both works have the 'dynamic dominant ending', which is typical of the genre; though in Vania the ending is more coda-like. As to their style, both novellas clearly bear the features of naturalism; in The Execution, there are more naturalistic details than absolutely necessary. Besides, Cherniava somewhat artificially makes his little 
criminals too 'spoilt' to fit the conception of aggression as the fundamental principle of human existence.

\section{REFERENCES}

[1] Гейзінга Й. Homo Ludens. Основи, К., 1994.

[Heizinha Y. Homo Ludens. Osnovy, K., 1994.]

[2] Кирилюк О.С. Універсалії культури і семіотика дискурсу. Новела: монографія. Астропринт, Одеса, 1998.

[Kyryliuk O.S. Universalii kultury i semiotyka dyskursu. Novela: monohrafiia. Astroprynt, Odesa, 1998.]

[3] Кундера М. Нарушенные завещания. СП., Азбука-классика, 2005.

[Kundera M. Narushennye zaveshchanyia. SP., Azbuka-klassyka, 2005.]

[4] Підмогильний В. Ваня. В: Підмогильний В.П. Оповідання. Повість. Романи. Наук. думка, К., 1991. [Pidmohylnyi V. Vania. In: Pidmohylnyi V.P. Opovidannia. Povist. Romany. Nauk. dumka, K., 1991.]

[5] Павдичко С. Дискурс модернізму в украӥнській літературі: монографія. Аибідь, К., 1999.

[Pavlychko S. Dyskurs modernizmu v ukrainskii literaturi: monohrafiia. Lybid, K., 1999.]

[6] Тарнавський М. Між розумом та ірраціональністю: Проза Валеряна Підмогильного. "Пульсари", К., 2004.

[Tarnavskyi M. Mizh rozumom ta irratsionalnistiu: Proza Valeriana Pidmohylnoho. "Pulsary", K., 2004.]

[7] Фройд 3. Вступ до психоаналізу. Основи, К., 1998.

[Froid Z. Vstup do psykhoanalizu. Osnovy, K., 1998.]

[8] Чернява I. Екзекуція. В: “Дванадиялтка". Наймолодиа львівська літературна богема 30-х років XX століттл: Антологія урбаністичної прози. "Піраміда", Аьвів, 2006.

[Cherniava I. Ekzekutsiia. In: "Dvanadtsiatka". Naimolodsha lvivska literaturna bohema 30-kh rokiv XX stolittia: Antolohiia urbanistychnoi prozy. "Piramida", Lviv, 2006.]

[9] Huizinga J. Homo Ludens: The Study of the Play Element in Culture. 1950/1955.

[10] Kundera M. Milan Kundera on ecstasy. Testaments Betrayed: An Essay in Nine Parts. Available at: https://www.cs.utexas.edu/users/vl/notes/kundera.html.

[11] Freud S. A General Introduction to Psychoanalysis "The Sexual Life of Human Beings", 1920. Available at: http://pages.uoregon.edu/eherman/teaching/texts/Freud\%20The\%20Sexual\%20Life\%20of\%20Human\% 20Beings.pdf.

Address: Natalia Maftyn, Vasyl Stefanyk Precarpathian National University, 57, Shevchenko Str., IvanoFrankivsk, 76025, Ukraine.

E-mail: natalimaftyn@gmail.com.

Received: 15.08.2017; revised: 03.10.2017.

Мафтин Наталія. Психоаналітичний дискурс української малої прози 20-30-х років XX століття. Журнал Прикарпатського університету імені Василя Стефаника, 4 (2) (2017), 54-62.

У статті йдеться про рецепцію ідей 3. Фройда українською прозою міжвоєнного двадцятиліття XX ст. Проаналізовано еросно-мортальну онтологічну парадигму як один із "модерних" алгоритмів побудови сюжету художнього тексту на прикладі творів В. Підмогильного та 
I. Черняви, досліджено їі вплив на специфіку моделювання конфлікту новели та характер його розвитку.

Домінантою письменницьких зацікавлень В. Підмогильного справедливо вважають увагу до “безсилля людської моралі перед спокусою злочину". Проаналізований у статті твір письменника студіює цю проблему на рівні онтогенезу душі на пубертативному етапі розвитку людської особистості. До теми неусвідомленої “спокуси здочину”, що еманує 3 жорстокої дитячої забавки, звернувся також I. Чернява. Тематична близькість двох творів, закорінений у фройдизмі алгоритм побудови сюжетів, стильова зорієнтованість на реалізм з елементами натуралізму дає змогу простежити специфіку такого типу модифікації структури тексту, в основі якої визначальну роль відіграє не стільки подієва сторона, скільки психодогічні зрушення, спровоковані нею.

В основі сюжетів обох художніх творів - стійкі структурно-поведінкові моделі дюдської культури (у "Вані" - модель ініціаційного випробування, в “Екзекуції” - перверзивна модель гри, суду, що трансформується в злочин). Новели мають специфічно оформлену експозицію, що знайомить читача 3 певними психічними нахилами персонажів та містить проекцію чільної проблеми. Тип фабули, що становить подієву основу сюжету, заявлений в обидвох творах вже у передісторії. Структура обох новел базується на паралелізації подій. Обидва твори у стидьовому плані яскраво позначені рисами натуралізму.

Ключові слова: еросно-мортальна парадигма, фройдизм, сюжет, новела, Vorgeschichte (передісторія), Shannung (новелістична напруга), онтогенез, ініціація, пуант (новелістичне загострення), кода, натуралізм. 